\title{
QUO VADIS PENENTUAN KAIDAH HUKUM BAGI SENGKETA PEGAWAI NEGERI SIPIL
}

Firman Firdausi; Fakultas Ilmu Sosial dan Ilmu Politik Universitas Tribhuwana Tunggadewi Malang, Jalan Telaga Warna Blok-C Kota Malang; E-mail : firman.firdausi.88@gmail.com

\begin{abstract}
Abstrak
Indonesia pada dasarnya memang merupakan negara hukum. Penegakan hukum dalam perkara-perkara sengketa Tata Usaha Negara juga harus berlandaskan hukum. Akan tetapi dalam suatu perkara tertentu terdapat adanya perbenturan antar kompetensi di dalam sistem peradilan dan sistem hukum di Indonesia. Salah satunya adalah dalam perkara nomor 533/K/TUN/2017 di mana melibatkan unsur pidana dan unsur tata usaha negara. Kesalahan (schuld) dari terpidana menyebabkan aparatur sipil negara terkena pemecatan. Prosedur pemecatan yang kurang tepat menjadi unsur keberatan dalam pemecatan dalam sengketa tata usaha negara ini sekalipun unsur kesalahan (pidana) secara jelas terbukti. Tujuan penelitian ini untuk mengetahui dan menganalisis dasar penentuan kaidah dalam sistem peradilan. Penentuan kaidah memerlukan analisis mendalam terhadap filsafat hukum. Melalui metode penelitian yuridis-normatif maka akan dijelaskan pemilihan atau dasar argumen Mahkamah Agung lebih menekankan aspek substantif daripada formil di dalam menyelesaikan perkara ini. Kaidah hukum substantif lebih menjadi landasan lebih tinggi dari kaidah hukum formil dan dipertegas kembali dalam SEMA Nomor 1 Tahun 2017. Melalui teori tiga nilai dasar Gustav dapat diketahui bahwa pemilihan kaidah substansi ini memiliki pertimbangan aspek keadilan (filosofis) dengan memperhatikan peristiwa konkret (sosio-empiris) sehingga bermanfaat bagi negara dan masyarakat.
\end{abstract}

Kata Kunci : Sengketa Tata Usaha Negara, Kaidah Hukum, Keadilan Substantif

\begin{abstract}
The Indonesia country are based rechstate (law-state). All about law enforcement for administration case must be based on law. One of many cased about administration case was inside there conflict of norm. This norm about authority or competencies of court in the legal system in Indonesia. In case number 533/K/TUN/2017 there are involves penal code system and state administration. Criminal (schuld) of the convict caused the state civil apparatus to be fired. However dismissal about procedure administration are become basic objection for administration case even the element of (criminal) error is clearly proven. The purpose of this research is to finding out and analyze the determination of rules in the justice system. This method of determination rules are required in-depth analysis of legal philosophy. Through the juridicalnormative research method, it will be explained the selection or the basis of the Supreme Court's argument emphasizes the substantive rather than the formal aspects in resolving this case. Substantive legal norms are a higher foundation than formal legal norms and are reaffirmed in SEMA Number 1 of 2017. Through the theory of three basic values, it can be seen that the selection of these legal norms has consideration of aspects of justice (philosophical) by paying attention to concrete (socio-empirical) events) so that it is beneficial for other countries and society.
\end{abstract}

Keywords : Administration Case, Pandect, Substantive Justice

\section{PENDAHULUAN}

\section{Latar Belakang}

Indonesia secara konstitusi memang berlandaskan negara hukum sebagaimana pasal 1 ayat 3 Undang-Undang Dasar Negara Republik Indonesia Tahun 1945. Sistem hukum peninggalan Eropa Kontinentalpun cukup membuat nuansa berdasar hukum menjadi cukup kental. Hal ini dipengaruhi paham-paham positivis yang juga berkembang di 
Indonesa. Sekalipun pada dasarnya semua harus berdasar hukum tidak berarti aparatur dalam penyelesaian konflik hukum hanya sebatas rule application. Perkembangan negara yang banyak menuju welfare state seiring dengan tujuan negara dalam alinea ke-4 yaitu kesejahteraan umum menjadikan perkembangan hukum menjadi beragam. Perkembangan ini dapat dilihat melalui studi sejarah negara Indonesia dari era orde lama sampai era reformasi.

Era reformasi di Negara Indonesia merupakan era dimana pemerintah melakukan perubahan-perubahan signifikan. Perubahan dilakukan bukan hanya berdasar tuntutan rakyat pada demonstrasi besar di akhir periode orde baru, namun juga sebagai kebutuhan terpenuhinya pelayanan publik yang baik. Pelaksanaan pelayanan publik yang baik di sini tentunya memiliki standar yang jelas. Asas yang digunakan dalam penerapan standar pemerintah dimulai dengan adanya AUPB, yaitu Asas Umum Pemerintahan yang Baik. Asas ini pertama kali tertuang ke dalam Undang-Undang Nomor 28 Tahun 1999.

Asas Umum Pemerintahan yang Baik kemudian sering dikenal dengan istilah Good Governance dalam perspektif beberapa ilmu pemerintahan. Asas pada dasarnya menjadi nilai yang mendasari suatu norma. Pengembangan asas ini kemudian banyak di aplikasikan ke dalam sendi-sendi pemerintahan bahkan sampai pada Undang-Undang tentang Pemerintahan Daerah.

Salah satu asas tersebut adalah asas profesionalitas. Penyelenggaraan pemerintah yang profesional menuntut pelaksanaan yang profesional dari segi aparatur sipil. Usaha pemerintah cukup beragam mulai dari mengeluarkan kebijakan moratorium Pegawai Negeri Sipil. Membuat Undang-Undang yang mengatur dan memisahkan antara Pegawai Negeri Sipil dan Pegawai Kontrak atau honorer untuk menutup akses masuknya honorer gelap yang merupakan celah dari perekrutan Pegawai Negeri Sipil itu sendiri.

Pada implementasinya tidak jarang juga ditemukan banyak masalah-masalah dalam mengatur jalannya kepegawaian negara. Permasalahan tersebut dapat dilihat dari tingkat pelanggaran yang dilakukan oleh pegawai negeri sipil. Mulai dari pelanggaran ringan sampai kepada pelanggaran berat.

Penegakan atas pelanggaran terhadap Pegawai Negeri Sipil tingkat ringan dapat diselesaikan secara mekanisme yang jelas dan kewenangan yang jelas. Bahkan sengketa antar pejabat pemberi sanksi kepegawaian dan pegawai yang dikenai sanksi dapat juga dibawa dan diselesaikan melalui Pengadilan Tata Usaha Negara.

Berbeda dengan tingkat pelanggaran berat yang memiliki unsur-unsur tindak pidana. Pada dasarnya, pejabat sebagai atasan langsung memiliki kewenangan untuk menghentikan pegawai negeri sebagai pelaku tindak pidana. Permasalahan terjadi ketika suatu pejabat merasa kewenangan dalam instansi lebih dominan sehingga terjadi adanya pertentangan kaidah hukum. Sebagaimana yang diketahui, bahwa asas praduga tak bersalah pun menjadi landasan bagi berlakunya tindak pidana bagi pegawai negeri sipil.

Salah satu contoh kasus adalah kasus sengketa Kepegawaian sebagaimana Putusan Mahkamah Agung nomor 533/K/TUN/2017. Pada kasus tersebut pejabat dari Pegawai 
Negeri Sipil telah memberikan sanksi administrastif berupa pemecatan kepada seorang pegawai negeri sebelum adanya putusan dari Pengadilan Negeri yang menyatakan terbukti bersalah. Pada dasarnya, sekalipun pejabat memiliki kewenangan untuk memberhentikan atau memberikan keputusan tata usaha negara, namun tetap memperhatikan kaidah hukum yang lainnya. ${ }^{1}$

Melalui beberapa permasalahan tata usaha negara ini peneliti tertarik untuk meneliti pertimbanga pemilihan kaidah substantif dan kaidah formil yang diterpakan dalam sistem peradilan di Indonesia.

\section{METODE PENELITIAN}

Pada penelitian hukum terdapat dua jenis yaitu normatif dan empiris. Penelitian hukum merupakan suatu bentuk penelitian ilmiah, yang mendasarkan setiap kegiatannya pada metode, sistematika dan pemikiran tertentu, yang tujuannya untuk menganalisa beberapa gejala hukum tertentu.

\section{Jenis Penelitian}

Tulisan ini sebagai penelitian dengan metode yuridis-normatif yang merupakan bentuk kegiatan penelitian ilmiah di bidang hukum dengan menggunakan metode meneliti data sekunder atau bahan kepustakaan. ${ }^{2}$ Dalam perspektif ini bahan pustaka seperti peraturan perundang-undangan, putusan hakim (yurisprudensi) dan norma ius constitutum merupakan sumber bahan hukum utama dan dasar.

\section{Pendekatan Penelitian}

Pada penelitian yang penggunakan jenis penelitian yuridis-normatif diperlukan pendekatan penelitian agar peneliti mendapatkan informasi secara filsafat-konseptual melalui pendekatan yang digunakan untuk menemukan jawaban atas isu terbaru yang menjadi bahannya. pendekatan penelitian yang digunakan dalam penelitian ini adalah sebagai berikut :

a) Pendekatan Filsafat merupakan pendekatan konseptual untuk memperoleh pemahaman yang lebih mendalam terhadap dampak sosial dan efek penerapan suatu tatana norma terhadap masyarakat atau kelompok masyarakat yang melibatkan penelitian terhadap sejarah, filsafat (teori), ilmu bahasa terhadap pemberlakuan suatu aturan hukum. Dalam penelitian ini, pendekatan filsafat berfungsi untuk mengetahui secara mendalam tentang kaidah hukum substantif dan kaidah hukum formil. Asal muasal penentuan kaidah dan tujuan penggunaan kaidah tersebut.

b) Pendekatan perundang-undangan atau pendekatan yuridis yang merupakan pendekatan yang harus mutlak digunakan dalam penelitian yuridis-normatif, karena isu utama yang dibahas adalah menyangkut putusan hakim (yurisprudensi)

1 Putusan Mahkamah Agung Nomor 533K/TUN/2017 perihal Kasasi Sengketa Kepegawaian antara Endri melawan Kepala Kepolisian Aceh, 30 November 2017.

2 Soerjono Soekanto dan Sri Mamuji, Penelitian Hukum Normatif Suatu Tinjauan Singkat, Jakarta: Raja Grafindo Persada, 2004, h. 13. 
terhadap penentuan kaidah substantif dan kaidah formil. ${ }^{3}$ Yurisprudensi tersebut adalah Yurispurdensi Mahkamah Agung Nomor 2/Yur/TUN/2018.

c) Pendekatan Konseptual (conceptual approach), pendekatan ini beranjak dari pandangan dan doktrin yang berkembang di dalam ilmu hukum. Peneliti diharapkan akan menemukan ide-ide yang melahirkan pengertian-pengertian hukum, konsep-konsep hukum dan bidang ilmu hukum. ${ }^{4}$ Konsep yang akan dikaji dalam penelitian ini yaitu Kaidah Hukum baik substantif, formil dan implikasi keadilannya.

\section{Sumber Bahan Hukum}

Penelitian hukum yang bersifat normatif selalu menitikberatkan pada sumber data sekunder. Data sekunder pada penelitian dapat dibedakan menjadi bahan-bahan hukum primer, bahan hukum sekunder dan bahan hukum tertier ${ }^{5}$. Dalam penelitian ini, bersumber dari data sekunder sebagai berikut :

a. Bahan hukum primer adalah sumber bahan hukum yang mengikat yang dalam penelitian ini terdiri atas :

1) Undang-Undang Nomor 48 tahun 2009 tentang Kekuasaan Kehakiman;

2) Undang-Undang Nomor 5 Tahun 1986 Jo Undang-Undang Nomor 51 Tahun 2009 tentang Peradilan Tata Usaha Negara.

3) Undang-Undang Nomor 5 Tahun 2014 tentang Aparatur Sipil Negara;

4) Peraturan Pemerintah Nomor 1 tahun 2003 tentang tentang Pemberhentian Anggota Kepolisian;

5) Surat Edaran Mahkamah Agung (SEMA) Nomor 1 Tahun 2017 tentang Pemberlakuan Rumusan Hasil Rapat Pleno Tahun 2017 sebagai Pedoman Pelaksanaan Tugas bagi Pengadilan;

6) Yurispurdensi Mahkamah Agung Nomor 2/Yur/TUN/2018.

b. Bahan-bahan hukum sekunder adalah sumber bahan hukum yang berhubungan dengan dan mendukung bahan hukum primer fungsi bahan hukum sekunder sebagai bahan analisis dan memahami bahan hukum primer. Bahan hukum sekunder ini terdiri dari buku-buku, hasil penelitian, hasil seminar, jurnal dan internet yang berkaitan dengan kaidah hukum.

c. Bahan hukum tertier adalah bahan hukum yang mendukung maupun penjelasan terhadap bahan hukum primer dan bahan hukum sekunder seperti kamus Besar Bahasa Indonesia.

\footnotetext{
${ }^{3}$ Peter Mahmud Marzuki, Penelitian Hukum, Jakarta : Kencana, 2005, h. 93

${ }^{4}$ Ibid, h.95.

5 Ronny Hanitijo Soemitro, Metodelogi Penelitian Hukum dan Jurimetri, Jakarta : Ghalia Indonesia, 1990, h. 11-12.
} 


\section{Metode Analisa Data}

Bahan-bahan hukum yang telah diperoleh kemudian diolah serta disajikan melalui langkah-langkah penelusuran hukum melalui metode deduktif rasional yakni menarik kesimpulan dari suatu pernyataan yang bersifat umum.

\section{PEMBAHASAN}

\section{Konsep Kaidah Hukum}

Pada pengertian menurut kamus besar bahasa Indonesia, salah satu pengertian kaidah justru tidak memiliki persamaan dengan definisi para ahli hukum. Pengertian kaidah berdasarkan kamus besar bahasa Indonesia yang pertama menyatakan bahwa kaidah adalah rumusan asas yang menjadi hukum. Kedua, aturan yang sudah pasti. Ketiga, dalil (dalam ilmu Matematika). Jika mengambil pengertian yang pertama, ditinjau dari pengertiannya berarti kaidah menurut pengertian ini merupakan hal yang lebih mendasar daripada asas hukum, bahkan unsur pembuatnya. Pengertian kedua dari kamus besar bahasa Indonesia dirasa lebih tepat menjelaskan pengertian dalil dalam perspektif ilmu hukum.

Pendapat ini sejalan dengan pengertian secara praktik dan pengertian ahli hukum seperti arief sidharta yang mengatakan bahwa asas adalah meta-kaidah, yang berarti justru lebih mendasar dari kaidah hukum. Kaidah dalam praktiknya selalu diidentikkan dengan norma. ${ }^{6}$

Norma sebenarnya merupakan bagian dari kaidah. Berdasarkan pengertian ini maka sebenarnya cakupan kaidah lebih luas daripada norma. Norma merupakan ketentuan yang mengatur tingkah laku manusia dalam masyarakat. Norma ada yang berlaku secara lingkungan dan masyarakat tertentu, ada yang berlaku universal seperti larangan membunuh atau mencuri. Kaidah hukum yang memiliki norma universal ini dijadikan landasan dalam pemberlakuan sanksi karena memiliki daya ikat dan kepastian. ${ }^{7}$

Kaidah Hukum memiliki dua sifat. Pertama, bersifat imperatif yaitu memiliki keharusan. Sifat ini dapat diketahui melalui daya paksa dan sifat pemaksaan yang berada di dalamnya. Kedua, bersifat fakultatif yang ditinjau dari asal katanya bersifat pilihan atau tambahan sehingga tidak memiliki daya paksa.

\section{Kaidah Hukum dan Keadilan Formal}

Kaidah hukum formal lebih mengarah kepada prosedural dimana lebih menitikberatkan kepada prosedur yang ada untuk menerbitkan suatu Keputusan Tata Usaha Negara. Kaidah hukum formal memang pada dasarnya melihat dari ranah sisi

\footnotetext{
${ }^{6}$ B. Arief Sidharta, Refleksi tentang Struktur Ilmu Hukum Indonesia. Sebuah Penelitian tentang Fundasi Kefilsafatan dan Sifat Keilmuan Ilmu Hukum sebagai Landasan Pengembangan Ilmu Hukum Nasional Indonesia, Bandung : CV. Mandar Maju, 2009, h.60 .

7 Efran Helmi Juni, Filsafat Hukum,. Filsafat Hukum. Bandung : Pustaka Setia, 2012, h. 397
} 
keadilan formal yang artinya bersifat adil ketika sudah dijalankan sesuai prosedur yang ada. 8

Konsep keadilan prosedural (formil) berhubungan dengan gaya suatu sistem hukum seperti rechstaat. Biasanya aparat banyak dalam sistem hukum civil law yang menganut aliran positivistik dan menghasilkan keadilan seperti ini. Keadilan formil disimpulkan bahwa keadilan didapatkan dari suatu putusan lembaga resmi yang dibentuk menurut undang-undang negara. ${ }^{9}$

\section{Kaidah Hukum dan Keadilan Substantif}

Kaidah hukum substansi merupakan kaidah hukum yang bersifat lebih mendasar yang dalam hal ini merupakan kewenangan Pejabat Tata Usaha Negara terkait. Kaidah Aturan kewenangan yang sudah jelas terdapat dalam sebuah aturan kepegawaian merupakan menjadi perangkat substansi yang dipergunakan dalam memproses setiap Keputusan Tata Usaha Negara. Kaidah hukum substantif pada dasarnya melihat dari ranah sisi keadilan materi yang artinya melihat pokok permasalahan yang terjadi.

Pada masyarakat, konsep keadilan masih cukup sulit untuk dipahami karena bersifat abstrak. Keadilan substantif memperhatikan hak-hak sosial, penataan sistem politik,hukum, ekonomi dan masyarakat. Konsep keadilan ini berakar dari kondisi masyarakat. Oleh karena itu jenis keadilan inilah yang dituntut hadir dalam masyarakat di era sekarang.

\section{Teori Tiga Nilai Dasar Hukum Gustav}

Pada penelitian ini digunakan teori Gustav Radburch. Teori tentang tiga nilai dasar hukum merupakan perkembangan dari teori-teori sebelum gustav. Gustav Radbruch yang berusaha mengkombinasikan ketiga pandangan klasik (filosofis, normatif-juridis dan empiris-sosilogis) menjadi satu pendekatan dengan masing-masing pendekatan dijadikan sebagai unsur pokok dan menjadi dasar pendekatan hukum yang identik dengan Radbruch. Tiga kombinasi ini kemudian dikenal sebagai tiga nilai dasar hukum yang meliputi; keadilan (filosofis), kepastian hukum (juridis) dan kemanfaatan bagi masyarakat (sosiologis). Gustav Radbruch memiliki pandangan bahwa masyarakat (sosial) dan ketertiban memiliki hubungan yang sangat erat, bahkan dikatakan sebagai dua sisi mata uang, hal ini menunjukkan bahwa setiap komunitas (masyarakat) di dalamnya membutuhkan adanya ketertiban. ${ }^{10}$

Peneliti menggunakan teori milik gustav sebab muncul penggunaan tiga nilai dasar ini dalam SEMA Nomor 1 Tahun 2017. SEMA ini merupakan salah satu dasar

\footnotetext{
8 Daniel S.Lev dalam Buku Mulyana W.Kusumah, Hukum, Keadilan, dan Hak Asasi Manusia, Suatu Pemahaman Kritis, Bandung : Alumni, 1987, h. 53

${ }_{9}$ Mulyana W. Kusumah, Hukum, Keadilan, dan Hak Asasi Manusia, Suatu Pemahaman Kritis, Bandung : Alumni, 1987.

10 M. Muslih, Negara Hukum Indonesia dalam Perspektif Teori Hukum Gustav Radbruch (Tiga Nilai Dasar Hukum), Legalitas: Jurnal Hukum Unbari, Volume IV, Nomor 1, Juni 2013, h.135
} 
pertimbangan hakim dalam menyelesaikan kasus-kasus penyelesaian kaidah substantif dan kaidah formil.

\section{Teori Ratio Decicendi}

Teori ini merupakan teori dalam penjatuhan putusan oleh hakim. Teori digunakan dalam menganalisis alasan-alasan batin (nurani) hakim dalam penjatuhan putusan. Selain itu dalam teori ini juga menjelaskan penggunaan keadilan formil dan keadilan substantif dalam penjatuhan putusan pada perkara atau kasus. Teori ini pada awalnya diciptakan terhadap kritik pada kasus pemidanaan yang disebabkan hakim hanya sebatas menegakkan keadilan formil atau sebagai corong undang-undang. ${ }^{11}$

Dasar pemikiran dari teori ini berangkat dari landasan filsafat penentuan keadilan substantif dengan mempertimbangkan segala aspek selain aspek formil. Aspek aspek itu antara lain keadilan, kemanfaatan, kemanusiaan, pendidikan, law enforcement, kepastian, dan banyak aspek lainnya.

\section{Quo Vadis Penentuan Kaidah Hukum}

Makna Quo Vadis dalam terminologi adalah hendak kemana. Berdasarkan dari definisi tersebut maka dalam hal ini menjelaskan tujuan, Tujuan yang ingin dicapai dalam situasi dan keadaan tertentu. Perbenturan kaidah hukum formal dan kaidah hukum substantif merupakan salah satu dari sekian banyak permasalahan peradilan di tingkat Peradilan Tata Usaha Negara. Biasanya perbenturan kaidah ini terjadi ketika akan menetapkan status subyek hukum yang termuat dalam Keputusan Tata Usaha Negara.

Pengertian Keputusan Tata Usaha Negara menurut Pasal 1 Nomor 3 UndangUndang Nomor 51 Tahun 2009 Juncto Pasal 1 Nomor 9 Undang-Undang Nomor 5 Tahun 1986 tentang Peradilan Tata Usaha Negara yaitu "Keputusan Tata Usaha Negara adalah suatu penetapan tertulis yang dikeluarkan oleh badan atau pejabat tata usaha negara yang berisi tindakan hukum tata usaha negara yang berdasarkan peraturan perundang-undangan yang berlaku, yang bersifat konkret, individual, dan final, yang menimbulkan akibat hukum bagi seseorang atau badan hukum perdata". Sedangkan dalam Undang-Undang Nomor 30 Tahun 2014 tentang Administrasi Pemerintahan mendefiniskan sebagai Keputusan Administrasi Pemerintahan yang menyamakan kedudukannya dengan Keputusan Tata Usaha Negara.

Berdasarkan pengertian dari Undang-Undang tersebut maka di dapat unsur-unsur wajib yang harus tersedia di dalam Keputusan Tata Usaha Negara, yaitu :

1. Keputusan dalam bentuk penetapan tertulis;

2. Diterbitkan oleh Badan/Pejabat Tata Usaha Negara (berupa tindakan hukum);

3. Berdasarkan peraturan perundang-undangan;

4. Bersifat Konkret, Individual, dan Final;

5. Menimbulkan akibat hukum bagi subyek hukum (individu atau badan hukum perdata).

11 Ahmad Rifai. Penemuan Hukum oleh Hakim dalam Perspektif Hukum Progresif. Jakarta : Sinar Grafika, 2010, h. 110 
Berdasarkan dari unsur tersebut maka dapat dianalisis dari yang pertama yaitu penetapan dalam bentuk tertulis, yaitu Surat Keputusan Kepala Kepolisian Daerah Aceh Nomor Kep/Khirdin-183/VII/2016. Kedua, diterbitkan oleh Pejabat Publik, dalam hal ini adalah Kepala Kepolisian Daerah Aceh. Unsur kedua dan ketiga inilah yang menjadi permasalahan. Ketiga, berdasarkan peraturan perundang-undangan. Pada poin ini yang utamanya menjadi perbedaan antara penggugat (Endri) dan tergugat (Kepala Kepolisian). Penggugat menggunakan pasal 15 Peraturan Pemerintah Nomor 1 tahun 2003 sebagai dasar keharusan untuk pemecatan dirinya yang harus didasari oleh vonis dirinya. Selain itu yang berhak melakukan pemecatan terhadap dirinya adalah Presiden Republik Indonesia atau Kepala Kepolisian Republik Indonesia bukan Kepala Kepolisian Aceh. Sedangkan Kepala Kepolisian berdasarkan kepada pasal 12-14 Peraturan Pemerintah tersebut yang menyatakan melakukan tindak pidana. Hal inilah yang kemudian menjadi sengketa tata usaha negara ini. Keempat bersifat konkret, individual dan final. Satu kesatuan unsur konkret individual dan final merupakan bentuk karakteristik dari KTUN. Surat Keputusan pemberhentian memenuhi aspek ini sebab di dalamnya termuat atas nama individu Endri sebagai subyek hukum, final dan konkret dalam hal ini adalah tidak ada lagi bentuk eksekusi selain dari Surat Keputusan itu sendiri. Surat tersebut berlaku langsung mulai tanggal diterbitkannya, itulah yang bersifat final dan konkret. Berakibat Hukum bagi individu atau badan hukum perdata. Akibat hukum jelas terjadi pada keluarnya Surat Keputusan tersebut yaitu hilangnya status hukum Endri sebagai aparatur sipil dan keanggotaan kepolisian termasuk hak beserta kewajibannya.

Pada kasus-kasus tata usaha negara selain asas hukum administrasi negara itu sendiri, asas good gorvernance atau AUPB juga menjadi landasan yang wajib dalam menimbang KTUN tersebut apakah sah atau tidak. Keberatan penggugat selain dari unsur KTUN tersebut antara lain telah dilanggarnya tenggat waktu Badan Pertimbangan Kepegawaia (BAPEK) yang melebihi prosedur yaitu melebihi 180 hari. Inilah yang menjadi dasar dari kaidah formil. Penggugat melihat bahwa keadilan formil merupakan keadilan yang perlu ditegakkan. Peristiwa ini sering disebut sebagai gugatan fiktifpositif. Sejak diberlakukannya Undang-Undang Administrasi Pemerintahan, gugatan fiksi negatif sudah tidak lagi digunakan karena mengakibatkan hilangnya kepastian hukum. Asas fiktif-positif ini sebenarnya mewajibkan Pejabat Publik untuk bertindak sesuai prosedur.

Pada sengketa kepegawaian melalui metode yuridis-normatif dapat dianalisis melalui yurisprudensi mahkamah agung. Yurisprudensi mahkamah agung yang dikaji lebih dalam ini adalah pada penentuan kaidah formal dan kaidah substantif merupakan kajian dari beberapa putusan yang pernah di keluarkan. Pada penelitian ini penelitian mengambil sampling putusan kasasi Nomor 533 K/TUN/ 2017 dengan para pihak Kepala Kepolisian Daerah Aceh melawan Endri Mahara.

Pada posita dari putusan di tingkat pertama dapat diketahui bahwa kronologis dikeluarkannya Objek Gugatan TUN Surat Keputusan Kepala Kepolisian Daerah Aceh 
Nomor Kep/Khirdin-183/VII/2016, tanggal 29 Juli 2016 tentang Pemberhentian Tidak Dengan Hormat Dari Dinas Polri kepada Endri Mahara merupakan suatu pertimbangan yang cukup jelas dikarenakan yang bersangkutan positif menggunakan methampetamin sebagai salah satu jenis narkotika golongan I. Sekalipun secara hukuman disiplin yang lain seperti menelantarkan dan/atau melakukan kekerasan pada istri seperti yang tertulis pada laporan Nomor LP/04/III/2015/Sipropam polda aceh sebagai pendahuluan untuk memenuhi sidang kode etik pada penggugat Endri Mahara. Problema yuridis-normatif dalam kasus ini sebenarnya terletak pada lewatnya tenggat waktu.

Pertimbangan Mahkamah Agung dalam memilih keadilan substantif daripada formal ditinjau dari amar putusan yang menyatakan

“... Bahwa pemerintah terutama Polri saat ini sedang gencar memberantas narkoba, dan oleh karena itu setiap anggota Polri termasuk Penggugat/Termohon Kasasi harus bertanggung jawab mendukungnya".

Pertimbangan substantif lebih mengarah kepada penegakan hukum secara peraturan yang bersifat materi (hukum pidana materiil) yaitu Undang-Undang Narkotika.

Pertimbangan keadilan substantif atas kasus tersebut diperkuat kembali ke dalam putusan No. 193 PK/TUN/2017 yang menyatakan :

"Bahwa secara kasuistik apabila kepastian tentang hak dan posisi seseorang/subjek hukum telah diputuskan oleh pengadilan dengan putusan yang berkekuatan hukum tetap, maka akan sangat menciderai keadilan apabila keadilan substantif dipinggirkan pada saat bergesekan dengan aturan formal, karena hukum acara dibuat semata-mata adalah untuk menegakkan kaidah hukum substansi. Pikiran seperti inilah yang diamanatkan oleh UUD NRI Tahun 1945 bahwa tugas Kekuasaan Kehakiman yaitu menegakkan hukum berdasarkan keadilan".

Oleh karena itu sikap atas pertimbangan Mahkamah Agung menunjukkan adanya pemilihan ke arah keadilan substantif daripada keadilan formil.

Teori Gustav digunakan dalam menganalisis pertimbangan ini dikarenakan ada beberapa faktor yuridis. Pertama, teori ini disebutkan ke dalam SEMA Nomor 1 Tahun 2017 pada kamar Peradilan Tata Usaha Negara yang juga memperkuat pemilihan keadilan substantif. Kedua, nilai dasar yang mendasari pemikiran gustav muncul dalam yurisprudensi Mahkamah Agung melalui Putusan No. 193 PK/TUN/2017 yang menyatakan bahwa

"Bahwa dengan demikian putusan Judex Juris yang lebih mengutamakan keadilan dan manfaat daripada kepastian hukum, adalah tepat dan benar".

Kepastian hukum cenderung mengarah kepada ranah formil atau prosedural sehingga seringkali mengorbankan keadilan itu sendiri. Oleh karena itu pertimbangan hakim dalam penentuan kaidah hukum substantif lebih diutamakan daripada kaidah hukum formal. Hal ini tentunya memperhatikan keadilan substantif dan keadilan formal.

Penggunaan ketiga komponen versi gustav diibaratkan di dalam realita masyarakat tersebut dimana kebiasaan lebih nampak pada perbuatan atau aktifitas yang memang sering dilakukan menjadi norma. Menurut Radbruch tatanan kebiasaan yang sering dilakukan ini pada dasarnya berbanding terbalik dengan hukum. Wujud hukum dalam 
kebiasaan ini disebut sebagai kesusilaan. Kebiasaan lebih menggambarkan posisi kebalikan dari kesusilaan. kebiasaan selalu berdasarkan pada "realita" tingkah laku manusia, maka kesusilaan justru berdasar pada sisi ideal yang "masih harus diwujudkan" dalam masyarakat. Untuk itu tolak ukur penilaian terhadap tindakan yang diterima atau ditolak didasarkan pada idealisme manusia yakni insan kamil atau manusia sempurna. Norma hukum lebih berorientasi pada dunia ideal (kesusilaan) dan realita (kebiasaan). Untuk memenuhi unsur ideal, hukum harus mengakomodir nilai filosofis dan guna memenuhi tuntutan kenyataan hukum harus memasukkan unsur sosiologis. ${ }^{12}$

Aspek kebiasaan terletak kepada kaidah prosedural dimana pada sengketa kepegawaian yang terdapat unsur pidana pada dasarnya mengacu kepada asas praduga tak bersalah yang menjadikan langkah penentu selanjutnya untuk melakuka kaidah subtansi. Hal inilah yang menjadi dasar keberatan dalam pengajuan gugatan dengan mengacu kepada pasal 14 Peraturan Pemerintah Nomor 1 tahun 2003. Sifat prosedural terletak pada nilai kepastian (juris). Kepastian di dalam sistem hukum eropa kontinental memang menjadi suatu hal yang wajib. Namun terdapat beberapa kelemahan jika hanya melihat dan menimbang dari segi aspek kepastian. Terutama jika nilai kepastian tersebut ternyata tidak memiliki unsur ideal (kesusilaan). Kebiasaan tidak selalu menjadi suatu hal yang pertama dan wajib (primus interpares). Kebiasaan penyelesaian permasalahan kepegawaian melalui jalur prosedural (kaidah formil) menjadi nilai kepastian (yuris) karena didukung oleh adanya peraturan-peraturan kepegawaian yang dijadikan dasar hukum. Pada permasalahan Endri Mahara melihat adanya peluang dalam nilai kepastian ini untuk dapat mempertahankan posisi dan statusnya sebagai pegawai negeri sipil. Peluang ini didapat karena pada Surat Keputusan pemecatannya tidak berdasarkan vonis hakim yang menyatakan dipidana atas penggunaan narkotika sebagai langkah awal kaidah substantifnya. Bantahan atas Surat Keputusan tersebut berdasarkan pasal 87 Undang-Undang ASN juncto pasal 12 Peraturan Pemerintah Nomor 1 Tahun 2003 tentang Pemberhentian Anggota Kepolisian yang menyatakan bahwa

"Anggota Kepolisian Negara Republik Indonesia diberhentikan tidak dengan hormat dari dinas Kepolisian Negara Republik Indonesia apabila: dipidana penjara berdasarkan putusan pengadilan yang telah mempunyai kekuatan hukum tetap dan menurut pertimbangan pejabat yang berwenang tidak dapat dipertahankan untuk tetap berada dalam dinas Kepolisian Negara Republik Indonesia ...".

Kepemilikan narkotika golongan I sebenarnya cukup untuk memvonis lebih dari dua tahun penjara berdasarkan pasal 87 Undang-Undang ASN jika diturunkan kepada status pegawai negeri sipil dan jika memag benar-benar diberhentikan dengan tidak hormat sudah melalui proses sidang kode etik berdasarkan pasal 12 Peraturan Pemerintah tersebut. Surat Keputusan yang dikeluarkan oleh Kepala Polres Aceh memang mendahului prosedural tanpa menunggu vonis hakim. Surat Keputusan dikeluarkan

${ }^{12}$ Gustav dalam Buku Bernard L Tanya, dkk. Teori Hukum : Strategi tertib Manusia, Yogyakarta: Genta Publisihing, 2013, h. 212 
berdasarkan pada bukti penggunaan narkotika dan pelanggaran-pelanggaran disiplin sebelumnya melalui sidang kode etik.

Kuatnya pertimbangan pemilihan kaidah substantif merupakan pencerminan dari asas ius curia novit sebagaimana Undang-Undang Kekuasaan Kehakiman. Tafsir dari penggunaan pasal-pasal baik di dalam Undang-Undang ASN maupun Peraturan Pemerintah tentag Anggota POLRI dapat dikaji dengan melalui interpretasi teleologis. Melalui metode interpretasi teleologis hakim dapat menyelesaikan adanya kesenjangan ataupun perbedaan dari sisi positif dan kenyataan hukum. Interpretasi teleologis melihat dari tujuan awal pembentuk Undang-Undang ataupun aturan tersebut. Tujuan awal dari pembentukan memiliki satu persamaan yaitu dengan adanya tindak pidana maka sudah termasuk pelanggaran kode etik berat yang dengan itu harus dikeluarkan menjadi abdi negara. Sekalipun pada kenyataannya terdapat kesenjangan antara fakta hukum pemakai narkotika dan sisi positif keharusan pemecatan dari organ tertinggi maka dengan ini hakim lebih memilih mempertimbangkan kepada fakta hukum sebagai keadilan subtansi.

Menimbang prinsip sistem peradilan tata usaha negara pada dasarnya tidak sama dengan sistem peradilan pidana yang memang cenderung kaku dan dibatasi oleh asas legalitas sifat pidana itu sendiri. Dapat dikatakan dalam kasus inilah yang menjadi pertentangan besar antara asas praduga tak bersalah dan asas praduga keabsahan dimana dalam kamar yang berbeda terjadi satu permasalahan. Hal inilah yang mendasari Mahkamah Agung mengeluarkan Surat Edaran Mahkamah Agung (SEMA) Nomor 1 Tahun 2017 tentang Pemberlakuan Rapat Pleno sebagai Pedoman Tugas bagi Pengadilan. Pada SEMA ini secara tersurat mempertegas pemilihan bahwa kaidah subtansi lebih fundamental dibandingkan kaidah formal. Tujuan dari SEMA itu sendiri adalah menghadirkan ketiga nilai sebagaimana yang dirumuskan oleh Gustav yaitu Kepastian, Keadilan dan Kemanfataan. Nilai ini secara tertulis bahkan di tuangkan ke dalam rumusan rapat pleno di kamar tata usaha negara yang menyatakan bahwa tujuan hukum acara peradilan tata usaha negara adalah menuju kebenaran materiil. Fungsi hukum acara PERATUN yang utama adalah untuk menegakkan kaidah hukum materiil/substantif. Dengan di utamakannya kaidah substantif sebagaimana interpretasi teleologis terhadap tujuan awal (materi pembentuk) undang-undang maka dirasa sejalan dengan pertimbangan hakim Mahkamah Agung pada kamar Tata Usaha Negara dengan memilih keadilan substantif. Pemilihan ini sebagai wujud spannungsverhältnis dan solusi atas penyelesaian di dalam permasalahan hukum yang di terapkan pada PERATUN.

Definisi spannungsverhältnis dalam gustav yang pada dasarnya menggabungkan tiga nilai menjadikan kepastian hukum tidak dapat berdiri sendiri. Nilai dasar yang terdapat dalam teori gustav ini dapat di jelaskan melalui alirannya yang menyatakan bahwa Kepastian Hukum normatif terjadi saat suatu norma dibuat secara pasti, mengatur secara jelas, tidak menimbulkan keragu-raguan, juga tidak berbenturan dengan norma lainnya. Berangkat dari dasar tersebut bahwa hukum yang berhasil adalah yang berangkat dari keadilan dan menjamin banyak kepastian sehingga menjadi hukum yang bermanfaat. Keadilan di sini merupakan hal yang substantif karena mengacu kepada asal tujuan 
pembentuk Undang-Undang. Pertimbangan keadilan substantif ini dapat dilihat dari yurispridensi tersebut yang berbunyi

"Bahwa pemerintah terutama Polri saat ini sedang gencar memberantas narkoba, dan oleh karena itu setiap anggota Polri termasuk Penggugat/ Termohon Kasasi harus bertanggung jawab mendukungnya."

Proses pemilihan akan substansi (materi) dan formil di sini terdapat beberapa sudut pandang yang digunakan oleh para hakim tata usaha negara dalam menyelesaikan kasus ini. Pemilihan ini mengacu kepada pengertian sumber hukum. Sumber hukum pada dasarnya terdiri dari dua jenis yaitu formil dan materiil. Sumber hukum formil yang sering dijadika dasar pemberlakuan utama di dalam eropa kontinental seperti Indonesia selama ini selalu dijadikan dasar utama dan wajib. Sedangkan sumber hukum materiil merupakan sumber hukum yang mengarah kepada dasar pembentukannya. Hakim tata usaha negara sebagaimana yang disepakati dalam SEMA Nomor 1 tahun 2017 memberikan pilihan kepada materiil yang lebih utama. Materiil inilah sebagai pembentuk kaidah substantif. Kaidah formil sebenarnya menitikberatkan pada keberlakuan hukum itu sendiri, sedangkan kaidah subtansi menitikberatkan pada makna (moral) kehidupan manusia.

Kedua, berdasarkan sifat keadilan. Keadilan yang dimaksud di sini masih berhubungan dengan terminologi dari formil yang berupa prosedur dan keadilan substantif yang berupa materi. Pada permasalahan sengketa kepegawaian seperti pada kasus Endri melawan Kepala Kepolisian Aceh menjadi hal yang cukup jelas bahwa akan timbul dimana dalam satu permasalahan akan melibatkan beberapa kamar peradilan, baik dalam kamar pidana maupun kamar yang lain. Untuk dapat menyelesaikan sengketa kepegawaian yang melibatkan kamar tata usaha negara dan kamar pidana seperti dalam kasus ini kemudian disepakati pemilihan kaidah substantif.

Masalah keadilan terhadap yurisprudensi tentang sengketa kepegawaian ini wajib dipahami dulu konsep keadilan. Konsep keadilan dalam filsafat hukum dapat membedah essensi pemilihan keadilan tersebut. Noah Webster (1997:993) memberikan beberapan definisi keadilan seperti :

1. Kualitas untuk menjadi pantas;

2. Tidak memihak, representasi yang layak atas fakta;

3. Kualitas untuk menjadi benar;

4. Penggunaan kekuasaan untuk mempertahankan kebenaran;

5. Alasan yang logis,valid.

Pada Teori Gustav nilai keadilan adalah sebagai nilai filosofis. Berangkat dari nilai tersebut ketika dilakukan konstruksi atas nilai keadilan ini maka nilai keadilan akan cenderung mengarah ke sisi ideal. Ideal yang dimaksud dalam Gustav ini adalah kesusilaan. Pemilihan keadilan berdasarkan kesusilaan ini nampak dalam petimbangan putusan dengan mengedapankan kesusilaan yang harus ditaati dalam realita masyarakat seperti pemberantasan narkotika. 
Unsur kesusilaan terhadap perlindungan masyarakat dari penyalahgunaan narkotika merupakan nilai filosofis yang menjadi dasar pertimbangan oleh hakim. Berangkat dengan jelasnya unsur kesusilaan ini maka putusan dan yurisprudensi ini sudah dianggap adil (fair). Norma hukum lebih berorientasi kepada sisi ideal ini. Sebagaimana yang dijelaskan dalam konsep, norma merupakan bagian dari kaidah. Penggunaan nilai filosofis yang berangkat dari pertimbangan ini diharapkan menjadi tolak ukur kaidah subtantif yang dipergunakan dalam menyelesaikan kasus-kasus serupa.

Nilai keadilan Gustav berangkat dari aliran etis yang sangat kental dari aliran hukum alam (lex naturalis). Penjelasan keadilan versi aliran etis ini menyatakan bahwa nilai keadilan hukum kodrat lebih kuat dari hukum positif yang menyangkut essensi manusia. Hal inilah yang menjadikan keadilan substantif yang berangkat dari kaidah kesusilaan lebih kuat. Lex naturalis sendiri terdapat dua jenis, yaitu rasional (akal) dan irrasional (ilahi). Pada dasarnya nilai filosofi keadilan ala Gustav berkiblat pada naturalis law yang rasional versi Immanuel Kant. Konsep keadilan Kant menghasilkan dua sifat hukum alam yang rasional yaitu sisi rasionalistis dan idealistis. ${ }^{13}$

Keadilan substantif pemilihan dalam rasio adalah menentang perundang-undangan yang bersifat prosedur. Keadilan lebih bernilai jika dilihat dari essensinya yaitu kualitas menjadi benar. Keadilan ilahi memiliki nilai universal yang berasal dari nilai Ketuhanan yang hidup di masyarakat Indonesia sekarang.

Hal ini dapat dilihat bahwa kompleks peraturan perundang-undangan yang mengatur manusia dalam hal ini sengketa di dalamnya terdapat unsur keuniversalan seperti halnya dilarang mencuri, dilarang madat (memaku narkotika) dimana keuniversalan ini tidak dapat dibantahkan oleh aliran positivis murni sekalipun nilai keuniversalan itu tertulis dalam peraturan perudang-undangan.

Pada nilai universal yang diambil dari Ketuhanan bersifat abadi yang telah ditetapkan dalam . Tuhan adalah penyebab dari kekuasaan. Tuhan menyerahkan pilihan kepada manusia yang dalam hal ini adalah para hakim untuk menentukan kekuasaan dalam menegakkan keadilan. Kekuasaan atau hak agar pengaturannya terhadap orang lain diletakkan sebagai norma perbuatan yang diwajibkan merupakan hukum yang sesungguhnya.

Nilai empiris-sosiologis dalam pandangan Gustav dapat dijelaskan melalui beberapa pendekatan. Oliver Wonder Holmes menyatakan bahwa hukum tidak berasal dari logika, namun berasal dari pengalaman. Pendekatan melalui pandangan roscue pound sebagai penjelasan atas nilai sosio-empiris. Konsep law as social tool dalam kasus sengketa kepegawaian ini sebenarnya bukan hendak merubah keadaan sosial atau nilai sosial yang ada dalam masyarakat tapi mengantarkan ke ranah ideal seperti pada cita hukum Gustav. Pada praktiknya kasus-kasus yang berkaitan dengan pertimbangan keadilan

13 Efran, Op.Cit., h.300. 
substantif dan keadilan formil dilihat melalui pengalaman yang tertuang ke dalam putusan-putusan sejenis. ${ }^{14}$

Tarik ulur dalam tiga nilai dasar ini sebenarnya dapat dijelaskan dengan melalui grafik kaidah hukum dan kaidah lainnya sebagai berikut ${ }^{15}$ :

Bagan 1. Tiga Nilai Dasar Hukum

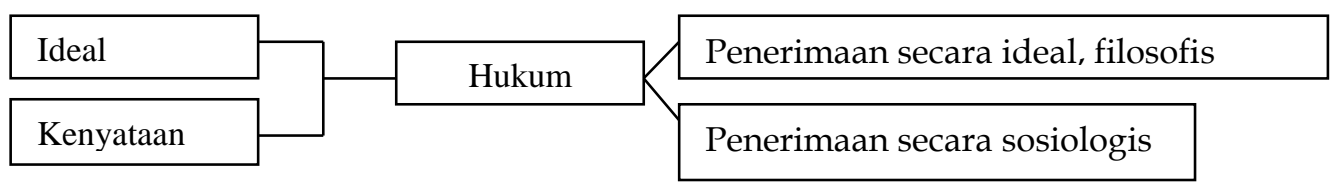

Kaidah hukum pada dasarnya bermacam-macam. Kaidah-kaidah yang terdapat di dalam kehidupan manusia bermacam-macam. Kaidah-kaidah ini diibaratkan sebagai sarang laba-laba (web) yang mengatur hubungan antar manusia. Dalam hubungan antar manusia, ada ragam kepentingan yang melekat kepada masing-masing individu baik itu itu sejajar, berlainan, atau bahkan berlawanan dalam usaha memenuhi kebutuhan. Oleh karena itu diperlukannya kaidah-kaidah tersebut agar semua berjalan tertib dan kedamaian terwujud.

Kaidah hukum memiliki kemandirian dalam berhadapan dengan ideal dan kenyataan. Posisinya sebagai mengambil jarak antara ideal dan kenyataan. Pada kasus sengeketa kepegawaian ini pada dasarnya pertimbangan sama-sama bersifat kaidah hukum. Oleh karena itu untuk dapat lebih dijelaskan kembali maka bagan 2 di bawah ini menjelaskan pemilihan kaidah hukum substantif dan kaidah hukum formil.

Bagan 2 Proses di dalam Kaidah Hukum, Kaidah Filosofis, dan Kaidah Empiris

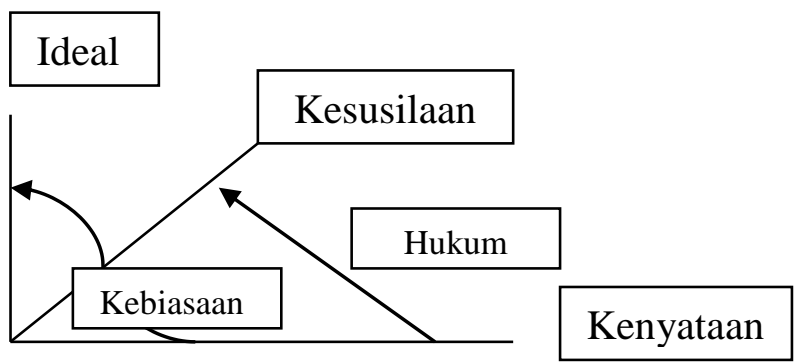

Kaidah kesusilaan yang menjadi "nilai keadilan" merupakan kaidah yang ada hubungannya dengan dunia ideal. Ideal inilah yang menjadi tolak ukur untuk menilai oleh hakim PERATUN terhadap tingkah laku anggota masyarakat. Pada kaidah kesusilaan unsur kehendak manusia tidak ikut menentukan. Kaidah hukum justru

14 Oliver Wonder Holmes sebagai salah satu pencetus teori hukum otonom. Konsep dalam teori ini menyatakan bahwa peraturan perudang-undangan yang bersfat umum-abstrak tidak dapat seketika diaplikasikan pada peristiwa konkret secara langsung. Peristiwa ini membutuhkan keahlian dalam penafsiran. Selain itu perlu kecermatan dalam melihat peristiwa hukum dan peristiwa konkretnya. Achmad Ali, Menguak Tabir Hukum, Bogor : Ghalia Indonesia, h.153

${ }^{15}$ Lili Rasjidi, Pengantar Filsafat Hukum, Bandung : Mandar Maju, 2007, h. 27 
melepaskan keterikatannya pada kenyataan. Tuntutan dalam pewujudan ideal ini adalah agar manusia menjadi insan kamil atau manusia sempurna.

Tuntutan ini diharapkan mampu diterapkan oleh hakim-hakim setelah yurispuredensi tentang sengketa kepegawaian ini untuk mewujudkan insan kamil tersebut. Hakim dianggap bukan hanya sebagai pelaksana atau sekedar penegak hukum tetapi sebagai penentu norma dan pengembalian nilai-nilai sosial yang sempurna (ideal).

Dasar pertimbangan oleh hakim kamar PERATUN dan hakim kamar pidana dalam menyelesaikan pokok-pokok perkara yang bersinggungan antara kaidah hukum formil dan kaidah hukum substantif dapat dianalisa melalui teori Ratio Decicendi. Teori ini memiliki landasan filsafat yang mendasar. Segala aspek menjadi bahan pertimbangan dan memperhatikan segala pokok peraturan perundang-undangan.

Landasan filsafat dalam teori ini bertumpu pada pertimbangan hakim dalam menjatuhkan putusan. Berangkat dari asas ius curia novit, bahwa sejatinya hakim bukan sebatas menerapkan hukum tetapi juga mempertimbangkan segala aspek baik itu keadilan, kemanusiaan, kemanfaatan, kepastian, ketertiban dalam sistem hukum.

Teori Ratio Decicendi ini berujung untuk memberikan keadilan (sisi filosofis-ideal) dalam suatu perkara. Hakim diperbolehkan mempergunakan hati nurani serta pengalaman kerjanya dalam menyelesaikan perkara-perkara sejenis. Teori ini menjelaskan bahwa putusan hakim tidak hanya bergantung pada keadilan formal (prosedural) namun juga keadilan substantif. ${ }^{16}$

Sisi perhatian dan pertimbangan hakim melalui keadilan prosedur melihat dari unsur Keputusan Tata Usaha Negara tersebut, baik dari unsur-unsur keabsahan putusan pemecatan sebagai anggota POLRI, namun dari sisi keadilan substantif hakim memiliki pertimbangan filsafat mengedepankan aspek gentingnnya kondisi yang lebih makro yaitu darurat narkotika. Narkotika termasuk dalam extra-ordinary crime sehingga membutuhkan penanganan lebih dari aparat penegak hukum.

Lembaga Kepolisian sebagai salah satu penegak hukum justru akan memiliki ancaman yang lebih berbahaya lagi jika ada anggotanya yang terlibat dalam narkotika itu sendiri. Pertimbangan ini sudah tertulis di dalam putusan dan juga yurisprudensi bahwa kondisi makro masalah narkotika adalah masalah yang perlu diperhatikan secara subtantif. Aspek pertimbangan inilah yang kemudian menjadi landasan filosofis sebagai keadilan substantif.

Teori ratio decicendi berlandaskan bahwa keadilan substantif berasal dari hati nurani hakim dan keadilan yang hidup di masyarakat. Hati nurani hakim dinyatakan dalam bentuk sikap batin (moral) dan jam terbang (pengalaman) penyelesaia perkara-perkara tertentu. Pada hukum acara PERATUN, alat bukti juga menyediakan slot atau wadah agar bentuk sikap batin dan pengalaman ini dapat diaplikasikan melalui "pendapat hakim". Akan tetapi banyak yang meragukan alat bukti ini karena bersifat abstrak dan terjadi kekhawatiran pengenaan unsur subyektifitas dalam penggunaan alat bukti ini.

16 Ahmad Rifai, Op.Cit, h. 110. 
Negara Indonesia yang menggunakan the binding of precedent tidak terlalu mengutamakan yurisprudensi sebagaimana negara-negara anglo saxon. Oleh karena itu pengertian yurisprudensi dalam penelitian ini perlu dibatasi yaitu putusan hakim yang telah memperoleh kekuatan hukum tetap dan dijadikan dasar oleh hakim-hakim setelahnya. ${ }^{17}$

Putusan-putusan tersebut antara lain :

1. $54 \mathrm{~K} / \mathrm{TUN} / 2014$

2. $193 \mathrm{PK} / \mathrm{TUN} / 2017$

3. $533 \mathrm{~K} / \mathrm{TUN} / 2017$

Putusan-putusan ini kemudian menjadi bahan untuk selanjutnya dituangkan menjadi yurisprudensi Mahkamah Agung di tahun 2018. Pada pertimbanganpertimbangan yurisprudensi tersebut secara jelas memilih keadilan substantif dan sudah menjadi ketetapan dan kebiasaan yang dianggap sebagai pemilihan sikap terhadap kasus serupa.

Mahkamah Agung dalam melakukan reformasi birokrasi telah menentukan sikap dalam mempetimbangkan segala aspek yuridis, filosofis, dan sosiologis agar keadilan seadil-adilnya dapat tercapai. Hal ini juga termaktub ke dalam cetak biru pembaharuan peradilan di Indonesia sebagaimana tertuang ke dalam rencana strategi pembaharuan peradilan 2010-2035. Melalui rencana strategis tersebut dan kebiasaan penelaahan kaidah hukum yang lebih substantif diharapkan menggeser dogma aparatur hanya sebagai rule application dan mewujudkan harapan keadilan yang diingankan oleh masyarakat dan negara, yaitu keadilan substantif.

\section{PENUTUP}

Berdasarkan hasil analisis terhadap pembahasan maka dapat disimpulkan bahwa penentuan kaidah hukum dalam menyelesaiakan sengketa kepegawaian yang terdapat pertentangan antara sistem Tata Usaha Negara dan Sistem Pidana memerlukan pemisahan antara kaidah hukum substantif dan kaidah hukum formil. Kaidah hukum sendiri terbagi antara kaidah substantif dan formil di dalam memutuskan perkara di Sistem Peradilan. Melalui SEMA Nomor 1 Tahun 2017 dan pertimbangan filsafat Gustav Radburch maka dalam perkara ini memiliki pertimbangan bahwa keadilan substantif penegakan hukum pada perkara pidana lebih diutamakan daripada keadilan formil (prosedural) pemecatan kepegawaian. Dengan menggunakan kaidah substantif maka dapat mewujudkan keadilan yang seadil-adilnya di dalam penyelesaian perkara sengketa kepegawaian. Hal ini mampu mewujudkan adil secara filosofis dan adil dalam sosioempiris.

Bagi aparat hukum hendaknya mempertimbangkan aspek kaidah substantif dengan melihat dan memperhatikan substantif dari peristiwa hukum itu sendiri sehingga aparat tidak hanya sebatas sebagai rule application.

17 M. Bakri, Pengantar Hukum Indonesia Jilid 1, Malang : UM Press, 2007, h. 87 


\section{DAFTAR PUSTAKA}

Buku

POKJA Yurisprudensi Mahkamah Agung. Yurisprudensi Tahun 2018. Jakarta : Biro Hukum dan Humas Mahkamah Agung, 2018.

Soerjono Soekanto dan Sri Mamuji, Penelitian Hukum Normatif Suatu Tinjauan Singkat, Jakarta: Raja Grafindo Persada, 2004.

Peter Mahmud Marzuki, Penelitian Hukum, Jakarta : Kencana, 2005.

Ronny Hanitijo Soemitro, Metodelogi Penelitian Hukum dan Jurimetri, Jakarta : Ghalia Indonesia, 1990.

B. Arief Sidharta, Refleksi tentang Struktur Ilmu Hukum Indonesia. Sebuah Penelitian tentang Fundasi Kefilsafatan dan Sifat Keilmuan Ilmu Hukum sebagai Landasan Pengembangan Ilmu Hukum Nasional Indonesia, Bandung : CV. Mandar Maju, 2009.

Efran Helmi Juni, Filsafat Hukum, Filsafat Hukum. Bandung : Pustaka Setia, 2012.

Mulyana W.Kusumah, Hukum, Keadilan, dan Hak Asasi Manusia, Suatu Pemahaman Kritis, Bandung : Alumni, 1987.

Buku Bernard L Tanya, dkk. Teori Hukum : Strategi tertib Manusia. Yogyakarta: Genta Publisihing, 2013.

Ahmad Rifai. Penemuan Hukum oleh Hakim dalam Perspektif Hukum Progresif. Jakarta : Sinar Grafika, 2010.

Achmad Ali, Menguak Tabir Hukum, Bogor : Ghalia Indonesia, 2015.

Lili Rasjidi, Pengantar Filsafat Hukum, Bandung : Mandar Maju, 2007.

M. Bakri, Pengantar Hukum Indonesia Jilid 1, Malang : UM Press, 2007.

\section{Peraturan Perundang-Undangan}

Undang-Undang Nomor 5 Tahun 2014 tentang Aparatur Sipil Negara

Undang-Undang Nomor 48 tahun 2009 tentang Kekuasaan Kehakiman

Undang-Undang Nomor 51 Tahun 2009 tentang Perubahan Kedua Peradilan Tata Usaha Negara

Undang-Undang Nomor 5 Tahun 1986 tentang Peradilan Tata Usaha Negara

Peraturan Pemerintah Nomor 1 tahun 2003 tentang tentang Pemberhentian Anggota Kepolisian

Surat Edaran Mahkamah Agung (SEMA) Nomor 1 Tahun 2017 tentang Pemberlakuan Rumusan Hasil Rapat Pleno Tahun 2017 sebagai Pedoman Pelaksanaan Tugas bagi Pengadilan

\section{Jurnal}

M. Muslih, Negara Hukum Indonesia dalam Perspektif Teori Hukum Gustav Radbruch (Tiga Nilai Dasar Hukum), Legalitas: Jurnal Hukum Unbari, Volume IV Nomor 1 Juni Tahun 2013. 